\title{
GNOSEOLOGICAL AND AXIOLOGICAL UNDERSTANDING OF PEDAGOGICAL WORKERS' LEGAL CULTURE IN PROFESSIONAL (VOCATIONAL) EDUCATION INSTITUTIONS
}

\author{
Radkevych Oleksandr, \\ $\mathrm{PhD}$ in Law, Senior Research Fellow, Research and Development Department, Institute of vocational education and training of \\ the National Academy of Educational Sciences of Ukraine \\ http://orcid.org/0000-0002-2648-5726 \\ e-mail:mr.radkevich@gmail.com
}

\begin{abstract}
The article deals with the epistemological and axiological essence of the legal culture of pedagogical workers of professional (vocational) education $(\mathrm{P}(\mathrm{V}) \mathrm{E})$ institutions. The concept of culture as a way and result of human activity is revealed. The attention is paid to epistemological understanding of culture, philosophical approaches to the definition of legal culture, issues of a modern teacher's legal culture development etc.

The normative consolidation of culture in the legislation of Ukraine is highlighted. It is established that culture is a social determinant: material achievements, spiritual and social values of a man/society while being; social rules and traditions expressed in the individuals' and society's behaviour; human characteristics in the context of good and evil social perception paradigm. The focus is on the $\mathrm{P}(\mathrm{V}) \mathrm{E}$ institutions teaching staff's legal culture as an important element of the system on establishing the rule of law in all spheres of public life, freedom, implementation of various spheres and of implementation forms for the national social and legal reform. The epistemological and axiological component of the legal culture is revealed. The broad and narrow decennial sense interpretation of legal culture is established. The attention is paid to determining the goal on pedagogical workers' legal culture forming as a system of legal knowledge and skills in combination with the personal and value component of vocational and pedagogical activities. It has been established that the epistemological and axiological essence of legal culture is considered as the legal consciousness of $\mathrm{P}(\mathrm{V}) \mathrm{E}$ institutions pedagogical workers. That is manifested through their attitude to personal interests, social values and norms of law.
\end{abstract}

Keywords: axiological, epistemology, culture, right, legal culture, pedagogical workers, professional (vocational) education institutions.

Introduction. Development of $\mathrm{P}(\mathrm{V}) \mathrm{E}$ institutions pedagogical workers' legal culture under current conditions becomes an integral part of their professional activity content, forms and methods. According to the results of conducted surveys among $\mathrm{P}(\mathrm{V}) \mathrm{E}$ institutions teachers, the share of legal nihilism in the pedagogical sphere is quite high and constitutes $63 \%$. Teachers do not have enough knowledge of educational legislation, as well as labour, civil, administrative and criminal law. After all, in many situations of the specified spheres they should take into account the right for written dispositive and imperative norms while their vocational and pedagogical activities. It is about the educators' use of legal norms while shaping the personality of future specialists by demonstrating their own value orientations, legal culture and life experience. In this context, the legal experience of a teacher covers his/ her legal consciousness, behaviour and activities.

From the point of view of pluralism, it is important to consider the legal culture of the $\mathrm{P}(\mathrm{V}) \mathrm{E}$ institutions teaching staff in the epistemological and axiological context. Indeed, such a context of understanding the legal culture is directly related to the spheres of human 
life where it is applied. At the same time, in each case there are differences in the understanding its components content due to the specifics of social roles.

Epistemological feature of the legal culture is its temporal boundaries, that is, the legal culture may belong in a certain epic, and may go beyond its limits; such a transition in the time frame is an ideal culture. Given the axiological understanding of legal culture, it is disclosed through legal values as certain social and legal phenomena, means and mechanisms of functioning.

Materials. The theoretical foundations of the study of gonoseologi -axiological understanding of $\mathrm{P}(\mathrm{V}) \mathrm{E}$ institutions pedagogical workers' legal culture are the works of domestic and foreign scholars on the following issues: philosophy of culture (P. Gurevich, A. Mogylny, M. Kagan, etc.), philosophy of law Golovchenko, O. Skakun, S. Stanik, etc.), philosophy of education (V. Andrushchenko, V. Kremen, V. Lutai, V. Ognevyuk, etc.).

An epistemological understanding of culture was studied by scientists through the relation of "culturenature" (M. Maksyuta, L. Sarakun, D. Pivovarov, T. Eliot), "natural-artificial" (K. Kyrylenko, P. Gurevich, etc.), "culture -civilization "(K. Zuev, O. Litvinov, O. Maltsev, etc.).

Philosophical approaches to the definition of the legal culture were substantiated by I. Nadolny, R. Serbin, V. Shishkin, I. Kovalenko, S. Slivka, G. Klimov, M. Kostytsky, V. Golovchenko, I. Sukhin, H. Solomchak and others.

The question of forming pedagogical workers' legal culture was investigated by N. Voplenko, M. Gorodysky, I. Dmitriyenko, V. Dubrovsky, V. Kopeychikov, V. Kotyuk, A. Morozov, M. Podberezsky and others. The components of the legal culture of a professional and, in particular, the content indicators of legal culture were the subject of the study of M. Keyserov, V. Kotyuk, V. Kryger, V. Oksamytnogo, A. Stakankov, V. Tyshchenko, M. Tsvika, V. Bezchastnogo, S. Goncharova and others.

Methodological, scientific and theoretical positions and stages of the pedagogical process of forming the legal culture are grounded by M. Gorodinsky, G. Yermoshin, O. Ihumnov, P. Musinov, S. Smirnov, S. Kruk, R. Klunko and others.

According to M. Gorodinsky (1999, p. 36), legal culture as a system of value orientations becomes the part of a person's general culture. To the content of legal culture, the scientist refers to the basic knowledge, new skills, emotional and value attitude to the facts, events and phenomena.

The axiological understanding of the legal culture is the guarantee of human rights and freedoms by the state. The inviolability of its life, health, honour and dignity are recognized as the highest social value (Official Bulletin of Ukraine, 2010, p.15).

A more profound understanding of the legal culture in the legal sense is formulated by O. Skakun (2005, p.743-745), revealing its structure, the scientist distinguishes four of its components: 1) legal consciousness; 2) legal behaviour and legal activity of citizens; 3) legal activity (legal practice). It includes: a) law-making activities and the state of law; b) judicial, law enforcement and other law-enforcement activities: 4) the state of law and order.

Focusing on the interpretation of legal culture in the legal sense is important to review the scientific approaches M. Sokolov (2004, p.389). He argues that it is unreasonable to consider the attribution of illegal behaviour (activities) to the elements of legal culture. Legal culture takes place when there is a systematic reproduction of the unity of legal knowledge, beliefs, values and practical activities with their implementation in the norm of behaviour, which became the general rule. That is why the deviation in behaviour from the requirements of law cannot be recognized as the content of legal culture. A. Oliynyk (2002, c.121) argues that the legal culture is "deep knowledge and understanding of law, the thorough fulfilment of its requirements as a conscious necessity and internal conviction." One must admit that not only rights but also human duties are an essential component of the legal culture of a person (Demin, 2006, p. 40).

Supplementing the definitive interpretation of scientists. S. Maksimov (2007, p.11) believes that legal culture can be regarded as a certain semantic unity, which consists of legal concepts, sources of law, legal methodology and legal argumentation, legitimisation of law. In turn, O. Demin (2005, p.74) argues that: "... in domestic law though the actual process of studying the problems of legal culture was actualized, but the latter works are of a narrowly applied nature, mainly connected with professional aspects of the legal category itself".

A more generalized understanding of legal culture is presented by N. Godun $(2015$, p.14), as due to all social, spiritual, political and economic development, a qualitative state of the legal life of society, expressed in the level of legal activity, legal laws, legal awareness, legal development the subject (a person, different groups, the whole population) development, as well as the degree of guarantee by the state and civil society of human rights and freedoms.

The research aim is to substantiate the epistemological and axiological foundations of understanding the $\mathrm{P}(\mathrm{V}) \mathrm{E}$ institutions pedagogical workers' legal culture.

Methods: theoretical: theoretical analysis, study of scientific literature, legislation - to find out the state 
of problem development and to determine the directions of scientific research; comparison - in order to study various scientific approaches to problem solving; analysis and synthesis - to substantiate the epistemological and axiological foundations of understanding the legal culture.

Results and discussions. The study of the epistemological and axiological nature of the legal culture is based on scientific approaches to the definition of the definition of "culture".

The important understanding of culture origin is the comprehension of its original source, namely, its epistemology. From the first person, the idea of mancenteredness began to emerge. Subsequently, the concept "I am the universe and the universe in the middle of me" developed.

The development of culture took place in the light of general postulates: language as a system of signs for the preservation, transformation and transmission of information; values; norms as an example of behaviour; knowledge and beliefs that reflect the natural and social nature of reality (Verbec, Sabbath and Christyuk 2009, p.241-242).

Let us turn to the epistemological component of culture. Thus, the notion "culture" has long been interpreted as the purposeful influence of man on nature (cultivation of land), as well as the education and training of the person himself(Dimokhkina, 2012, p.140. That manifests the desire of a man for comprehensive control and influence on both natural and human factors. Based on this, V. Voropaev (2013, p.253) argues that culture reflects a certain historical level of development of society and a man. It is revealed in the types and forms of organization of people life and activity, as well as in the material and spiritual values created by them.

L. Petruchak (2009, p.32), believes that the very concept of "culture" is an "axiological phenomenon", which involves "a deep awareness of the person and society in cultural and historical values," combining the numerous properties of culture around the notion of "value". That is defined from the inside, from the depths of an individual and social life. It is called the culture of the people and society.

Let us pay attention to the unification, categories of culture reflecting its properties. In the first case, the culture must understand all that was created by humanity in the process of its practical and spiritual activity; in the second - culture reflects the development of social abilities and qualities of people, the level and nature of mastering the best qualities on the basis of all social and personal experience (Salnikov, 1980, p.6). By combining these definitions, V. Borodin (1989, p.14), formed four groups of understanding of the social role, nature and content of culture. The first group is made up of definitions in which the culture is considered as a collection of organic for its substantive characteristics. The second group of definitions concentrates on the properties of culture to produce, distribute and use spiritual values (in this group the main factor is the social activity of man). The third, conventionally called technological, group of definitions explains culture as a system of methods and means, techniques, procedures and norms of human activity. The fourth group focuses on sociohistorical experience.

The top of public acceptance of culture and its scientific understanding is the normative setting in the law or any legislation document. It is recognized at the state and territorial level. In the Law of Ukraine "On Culture" (2011) this definition is defined as - a set of material and spiritual assets of a particular human community (ethnos, nation), accumulated, enshrined and enriched over a long period, passed from generation to generation, includes all kinds of art, cultural heritage, cultural values, science, education and reflects the level of development of this community. Given this definition, it can be argued that it is universal and not person-specific. That is a look at the culture in its original holistic-anthropomorphic sense.

Note that, in accordance with Clause 4, Article 1 of this Law (2011), the activities in the field of culture include creative, economic, scientific, library, information, museum, educational, culturalentertainment and entertaining activities, are defined. Thus, the legislator identified all the spectra of possible use of culture in the state and indicated that culture is aimed at satisfying the citizens' cultural needs. On the basis of this, one can understand that culture occupies an important place in the formation of a personality as a citizen and a professional in all its possible manifestations. Given that disciplinary, civil, administrative and criminal liability it is foreseen for breach cultural legislation where the understanding of its importance is. Thus, culture is a social determinant: material achievements, spiritual and social values of man / society in the process of being; social rules and traditions expressed in the behaviour of individuals and society; human characteristics in the context of the good and evil social perception paradigm.

The culture also understands the level of education, and the education of a person, and the level of mastering a certain branch of knowledge or activity (culture of production, culture of labour, language culture, legal, moral, aesthetic culture, culture of life, etc.) (Radkevych, 2010, p.108).

The important role in the professional activity of $\mathrm{P}(\mathrm{V}) \mathrm{E}$ institutions teaching staff is legal culture. Legal culture is an important part of the process on 
establishing the rule of law in all spheres of social life, freedom, implementation of various spheres and forms, and the implementation of a correct national socio-legal reform. Sustainable development of public perception and understanding the legal culture. It is an efficient mechanism for its observance functions and is the main, effective condition for the formation of democratic principles. Note that, according to the main principle of democracy, "power is in the people", legal culture in society should be based on legal experience, intellectual development, ideological and value system, legal world outlook and modern ideas of legal culture.

Legal culture has a strong epistemological (cognitive) basis, since it is intended to reveal the laws of legal knowledge. Under these conditions, epistemology of law appears as a connecting chain between a certain legal theory, its method and the fundamental philosophical and ontological principles on which they are based (Kozlovsky, 2005, p. 32).

Note that understanding the essence of the concept of legal culture is revealed within the axiological approach. So, O. Demin (2007, p.12-13) notes that legal culture is a multi-valued characteristic of one of the most important aspects of society's life, an integral part of its general culture with legal values and norms in the legal sphere of public life.

Axiological foundations of legal culture are represented by their own values of law in the practical life of people (guarantee of rights, freedoms, equality, justice); fundamental, natural human rights, basic democratic legal principles; special legal means and mechanisms (legal instruments) that provide the value of the right; institutions that express the optimum balance of normative and individual regulation, etc. (Polisuk, 2013, p.75-81).

The legal culture can be considered both broadly and narrowly. In the broad sense, the notion of legal culture can be understood: first, as a value, where the legal culture reflects the value-legal, ideological and legal state of society at a certain historical stage. It characterises the level of legal consciousness, understanding of law and respect for the law. There are several indicators of legal culture level. They are the level of legal opinions development, the guarantee of rights, the law enforcement activities level and the legal education and upbringing level. Secondly, this is a competent approach where the mandatory condition is the rejection of traditional normative guidance in favor of a value-based approach to law, from legal dogmatism to legal mechanisms active development and means of action. These requirements derive, first of all, from the practical value of legal knowledge for a citizen (Romanova, 2008, p.32).

In the narrow sense, the legal culture can be defined as a system of legal concepts and views, knowledge and expectations, skills and behavioural practices, legal values and social norms, evaluative judgments of social actors regarding the state of legal reality. They are socialised and entering the network socially -legal relations via that reality. They reveal civil-law activity, carry out the lawful conduct ensured by the legal coordination of personal (or group) and public interests (Ogarenko, 2013, c.13).

The purpose of $\mathrm{P}(\mathrm{V}) \mathrm{E}$ institutions pedagogical workers' legal culture is: firstly, purposeful mastering of legal knowledge; and secondly, the formation of emotional and value relation to legal values, moral norms, principles, ideals; thirdly, the formation of legal norms and principles of personal behaviour. The content of socio-cultural orientation includes social tolerance and cultural cooperation, stipulating legal activity and legitimate behaviour; fourth, the development of the ability to independently apply value knowledge, beliefs and principles in professional activities (Rem, 2012, p.70).

The content of $\mathrm{P}(\mathrm{V}) \mathrm{E}$ institutions pedagogical workers' legal culture development should also include the system of legal knowledge and skills in combination with the personal and value component of vocational and pedagogical activities, as well as knowledge of the principles of legal regulation of information in modern information and telecommunication networks, the Internet (Radkevych, 2012, p.436-443). Note that when a person acquires a body of legal knowledge in a person, a categorical apparatus is made. It regulates both the actions of the person and people. That in turn serves as a dynamic factor for common legal culture development.

$\mathrm{P}(\mathrm{V}) \mathrm{E}$ institutions teachers should be aware of the issues of jurisdictional and non-jurisdictional copyright and related rights protection for educational and methodological products created in the process of their vocational and pedagogical activities. Consequently, the pedagogical staff is expedient to improve knowledge and skills for copyright and related rights protecting by: right and void act recognition, offending right termination, restorating the situation existed prior to the violation, forced execution of the obligation in kind, legal relationship change, relationship termination, compensation, etc. (Radkevych, 2015, p.4).

In view of the above, the epistemological and axiological essence of legal culture is considered as the $\mathrm{P}(\mathrm{V}) \mathrm{E}$ institutions pedagogical workers' legal consciousness. It is manifested through their relation to personal interests, social values and norms of law. The special place is occupied by rights and freedoms determined by the state, when clear distinction is made between prohibited and non-prohibited types of vocational and pedagogical activities. 
Conclusions. Consequently, the epistemological and axiological understanding of $\mathrm{P}(\mathrm{V}) \mathrm{E}$ institutions pedagogical workers' legal culture the legal culture is based on certain cultures as social determinants for the people/society material achievements, spiritual and social values function in the process of being; social rules and traditions expressed in the individuals' and society's behaviour; human characteristics in the context of the good and bad social perception paradigm.

Therefore, legal culture is considered as a system of legal values reflecting the state of individual freedom, social values, legal knowledge and skills in combination with the personal and value component of vocational and pedagogical activity, the legal awareness of $\mathrm{P}(\mathrm{V}) \mathrm{E}$ institutions teaching staff. It is revealed through their relation to personal interests, social values and norms of law. The content of legal culture development should include social norms, tolerance, cultural cooperation and pedagogical interaction, lawful behaviour, legal knowledge, skills and principles use in vocational and pedagogical activities.

To this end, in further developments, the overview of the scientific approaches to $\mathrm{P}(\mathrm{V}) \mathrm{E}$ institutions teaching personnel's legal culture development should be conducted to improve the quality of their professional and pedagogical activities.

\section{List of references}

Бородин, В.В., 1989. Воспитание правовой культуры у молодых сотрудников милиции. Кандидат юридических наук. Институт государства и права имени В. М. Корецкого НАН Украины.

Вербець, В.В., Субот, О.А. та Христюк, Т.А., 2009. Соиіологія. Київ: КОНДОР.

Верховна Рада України. Законодавство України, 2011. Про культуру. Закон України від 14.12.2010 року № 2778VI [online] (Останнє оновлення 04 Листопад 2018) Доступно: <https://zakon.rada.gov.ua/laws/show/2778-17> (Дата звернення 28 Травень 2019).

Воропаєва, В.Г., 2013. Онтологічні засади культури як найвищої загальнолюдської цінності буття. Гуманітарний вісник Запорізької державної інженерної академії, 54, с. 251-265.

Годун, Н.Ю., 2015. Правова культура: дефініція поняття. Наше право, 1, с. 10-15.

Городиський, М.I., 1999. Педагогічні умови забезпечення змісту правової освіти майбутнього вчителя. Кандидат педагогічних наук. Харківський державний педагогічний університет ім. Г.С. Сковороди.

Димочкіна, В., 2012, Правова культура особистості у структурі філософського та психолого-педагогічного знання. Молодь і ринок, 12, с. 140-144.

Дьоміна, О.С., 2005. Деякі методологічні питання формування національної правової культури та їі функціональна роль у розвитку української державності. Часопис Київського університету права, 4, с. 74-77.

Дьоміна, О.С., 2006, Проблеми формування правової культури в Україні в умовах трансформації політичного режиму. Держава і право, 31, с. 39-44.

Дьоміна, О.С., 2007. Формування правової культури студентської молоді в умовах сучасного украӥнського суспільства. Кандидат юридичних наук. Національна академія наук України. Інститут держави і права ім. В.М. Корецького.

Козловський, А.А., 2005. Гносеологічні принципи права. Проблеми філософії права, 3(1-2), с.32-44.

Копєйчиков, В.В., ред., 2002. Правознавство. 7-е вид., Київ: Хрінком Інтер.

Максимов, С.І., 2007. Українська правова культура: ціннісний вимір. В: Битяк, Ю.П., Яковюк, І.В., Чапала, Г.В., ред. Правова культура і громадянське суспільство в Украӥні: стан і перспективи розвитку: Міжнародна наукова конференція. Харків, Україна, 12 жовтня 2007. Харків: Право.

Огаренко, Т.О., 2013. Політична та правова культура як чинник демократизації суспільства. Право та державне управління, 1(10), с. 13-17.

Петрущак, Л.А., 2009. Правовая культура: обоснование аксиологического подхода. Актуальные проблемы российского права, 3, с. 31-39.

Поліщук, П.В., 2013. Поняття правових цінностей та методологічні підходи до розуміння їх сутності. Філософські та методологічні проблеми права, 1-2, с. 75-81.

Радкевич. В.О., 2010. Теоретичні і методичні засади професійного навчання у закладах профтехосвіти художнього профілю. Київ: Укр IНТЕІ.

Радкевич, О.П., 2012. Особливості правового регулювання мережі Інтернет. Право та управління, 1, с. 436-443.

Радкевич, О.П., 2015. Розвиток правової компетентності педагогічних праиівників професійно-технічних навчальних закладів. Павлоград: ООО ІМА-прес.

Рем, О., 2012. Педагогічні умови формування правової культури педагога професійного навчання. Проблеми підготовки сучасного вчителя, 6, с. 68-73

Романова, І. Л., 2008. Компетентнісний підхід до правової освіти студентів. Збірник наукових пращь Харківського національного педагогічного університету імені Г. С. Сковороди: Педагогіка та психологія, 33, с. 26-35.

Сальников, В.П., 1980. Правовая культура и поведение советских граждан (вопросы теории). Кандидат наук. Ленинградский государственный Университет.

Скакун, О.Ф., 2005. Теория государства и права. Х.: Эспада.

Соколов, Н.Я., 2004. О понятии правовой культуры. Lex Russica, 2, c. 383-389. 


\section{Translated \& Transliterated}

Borodin, V.V., 1989. Vospitanie pravovoy kulturyi u molodyih sotrudnikov militsii [Training legal culture for young police workers]. Kandidat yuridicheskih nauk. Institut gosudarstva i prava imeni V. M. Koretskogo NAN Ukrainyi, [in Russian].

Verbets, V.V., Subot, O.A. ta Khrystiuk, T.A., 2009. Sotsiolohiia [Sociology]. Kyiv: KONDOR, [in Ukrainian].

Verkhovna Rada Ukrainy. Zakonodavstvo Ukrainy [Verkhovna Rada of Ukraine. Legislation of Ukraine], 2011. Pro kulturu [On culture]. Zakon Ukrainy vid 14.12.2010 roku № 2778-VI [online] (Ostannie onovlennia 04 Lystopad 2018) Dostupno: < https://zakon.rada.gov.ua/laws/show/2778-17> (Data zvernennia 28 Traven 2019), [in Ukrainian].

Voropaieva, V.H., 2013. Ontolohichni zasady kultury yak naivyshchoi zahalnoliudskoi tsinnosti buttia [Culture ontology basis as the highest general value of being]. Humanitarnyi visnyk Zaporizkoi derzhavnoi inzhenernoi akademii [Humanitarian Herald of Zaporizhzhia state engeneering academy], 54, s. 251-265, [in Ukrainian].

Hodun, N.Iu., 2015. Pravova kultura: definitsiia poniattia [Legal culture: definition of term]. Nashe pravo [Our right], 1, s. 10-15, [in Ukrainian].

Horodyskyi, M.I., 1999. Pedahohichni umovy zabezpechennia zmistu pravovoi osvity maibutnoho vchytelia [Pedagogical conditions for assuring the content of future teachers' legal education]. Kandydat pedahohichnykh nauk. Kharkivskyi derzhavnyi pedahohichnyi universytet im. H.S. Skovorody, [in Ukrainian].

Dymochkina, V., 2012. Pravova kultura osobystosti u strukturi filosofskoho ta psykholoho-pedahohichnoho znannia [An individual's legal culture in terms of philosophy and pedagogical knowledge]. Molod i rynok [Youth \& market], 12, s. 140-144, [in Ukrainian].

Domina, O.S., 2005. Deiaki metodolohichni pytannia formuvannia natsionalnoi pravovoi kultury ta yii funktsionalna rol u rozvytku ukrainskoi derzhavnosti [Some methodology issues on forming national legal culture and its function role for the Ukrainian statebeing development]. Chasopys Kyivskoho universytetu prava [Chasopys of Kyiv University of Law], 4, s. 74-77, [in Ukrainian].

Domina, O.S., 2006, Problemy formuvannia pravovoi kultury v Ukraini v umovakh transformatsii politychnoho rezhymu [Legal culture forming problems in Ukraine in terms of the policy regime transformation]. Derzhava i pravo [State and Law], 31, s. 39-44, [in Ukrainian].

Domina, O.S., 2007. Formuvannia pravovoi kultury studentskoi molodi v umovakh suchasnoho ukrainskoho suspilstva [Forming legal culture for the student youth in terms of modern Ukrainian society]. Kandydat yurydychnykh nauk. Natsionalna akademiia nauk Ukrainy. Instytut derzhavy i prava im. V.M. Koretskoho, [in Ukrainian].

Kozlovskyi, A.A., 2005. Hnoseolohichni pryntsypy prava [Hnoseology principles of the law]. Problemy filosofii prava [Philosophy of law] 3(1-2), s. 32-44, [in Ukrainian].

Kopieichykov, V.V., red., 2002. Pravoznavstvo [Legal knowledge]. 7-e vyd., Kyiv: Khrinkom Inter, [in Ukrainian].

Maksymov, S.I., 2007. Ukrainska pravova kultura: tsinnisnyi vymir [Ukrainian legal culture, values dimension]. V: Bytiak, Yu.P., Yakoviuk, I.V., Chapala, H.V., red. Pravova kultura i hromadianske suspilstvo v Ukraini: stan i perspektyvy rozvytku [Legal culture and society in Ukraine: state of arts and prospects]: Mizhnarodna naukova konferentsiia. Kharkiv, Ukraina, 12 Zhovten 2007. Kharkiv: Pravo, [in Ukrainian].

Oharenko, T.O., 2013. Politychna ta pravova kultura yak chynnyk demokratyzatsii suspilstva [Politics and legal culture as an indicator for the society democracy]. Pravo ta derzhavne upravlinnia [Law and public administration], 1(10), s. 13-17, [in Ukrainian].

Petruschak, L.A., 2009. Pravovaya kultura: obosnovanie aksiologicheskogo podhoda [Legal culture: grounding the axiology alproach]. Aktualnyie problemyi rossiyskogo prava [Actual Problems of Russian Law], 3, s. 31-39, [in Ukrainian].

Polishchuk, P.V., 2013. Poniattia pravovykh tsinnostei ta metodolohichni pidkhody do rozuminnia yikh sutnosti [Legal values issues and methodological approaches to their worth understanding]. Filosofski ta metodolohichni problemy prava [Philosophical and Methodological Problems of Law], 1-2, s. 75-81, [in Ukrainian].

Radkevych, V.O., 2010. Teoretychni $i$ metodychni zasady profesiinoho navchannia u zakladakh proftekhosvity khudozhnoho profiliu [Theoretical and methodological basics for professional training at arts profile vocational schools]. Kyiv: Ukr INTEI, [in Ukrainian].

Radkevych, O.P., 2012. Osoblyvosti pravovoho rehuliuvannia merezhi Internet [Features of legal regulating of the Internet]. Pravo ta upravlinnia [Law and Management 1, s. 436-443, [in Ukrainian].

Radkevych, O.P., 2015. Rozvytok pravovoi kompetentnosti pedahohichnykh pratsivnykiv profesiino-tekhnichnykh navchalnykh zakladiv [Legal competence development for pedagogical workers of vocational schools]. Pavlohrad: OOO IMA-pres, [in Ukrainian].

Rem, O., 2012. Pedahohichni umovy formuvannia pravovoi kultury pedahoha profesiinoho navchannia [Pedagogical conditions for legal culture forming of an industrial training teacher]. Problemy pidhotovky suchasnoho vchytelia [Problems of preparing a modern teacher], 6, s. 68-73, [in Ukrainian].

Romanova, I. L., 2008. Kompetentnisnyi pidkhid do pravovoi osvity studentiv [Competence-based approach for students' legal education]. Zbirnyk naukovykh prats Kharkivskoho natsionalnoho pedahohichnoho universytetu imeni H.S. Skovorody: Pedahohika ta psykholohiia [Scientific journals of H. S. Skovoroda Kharkiv National Pedagogical University], 33, s. 26-35, [in Ukrainian].

Salnikov, V.P., 1980. Pravovaya kultura i povedenie sovetskih grazhdan (voprosyi teorii) [Soviet citizens' legal culture and behaviour]. Kandidat nauk. Leningradskiy gosudarstvennyiy Universitet, [in Russian].

Skakun, O.F., 2005. Teoriya gosudarstva i prava [Theory of a state and law]. H.: Espada, [in Russian].

Sokolov, N. Ya., 2004. O ponyatii pravovoy kulturyi [On the concept of legal culture]. Lex Russica, 2, s. 383-389, [in Russian]. 


\section{Гносеологічно-аксіологічне розуміння правової культури педагогічних працівників закладів професійної (професійно-технічної) освіти}

\section{Радкевич Олександр,}

кандидат юридичнх наук, старший науковий співробітник науково-організаційного відділу, Інститут професійнотехнічної освіти НАПН України

Реферат. У статті висвітлено гносеологічно-аксіологічну суть правової культури педагогічних працівників закладів професійної (професійно-технічної) освіти. Розкрито поняття культури як способу та результату людської діяльності. Приділено увагу гносеологічному розумінню культури, філософським підходам до визначення правової культури, питанням розвитку правової культури сучасного педагога тощо.

Висвітлено нормативне закріплення культури в законодавстві України. Встановлено, що культура являє собою соціальну детермінанту: матеріальні досягнення, духовні і соціальні цінності людини / суспільства у процесі буття; суспільні правила і традиції, виражені у поведінці осіб і суспільства; характеристики людини в контексті парадигми соціального сприйняття добра і зла. Зосереджено увагу на правовій культурі педагогічних працівників закладів професійної (професійно-технічної) освіти як важливому елементу системи утвердження верховенства права у всіх сферах суспільного життя, свободи, реалізації різних сфер і форм здійснення національної соціально-правової реформи. Розкрито гносеологічно-аксіологічну складову правової культури, в ході чого встановлено дефеніціальне трактування правової культури в широкому та вузькому розумінні. Приділено увагу визначенню мети формування правової культури педагогічних працівників як системи правових знань і вмінь у поєднанні з особисто-ціннісним компонентом професійно-педагогічної діяльності. Встановлено, що гносеологічно-аксіологічна суть правової культури розглядається як правосвідомість педагогічних працівників закладів професійної (професійно-технічної) освіти, що виявляється через їх відношення до особистих інтересів, суспільних цінностей та норм права.

Ключові слова: аксіологія, гносеологія, культура, право, правова культура, педагогічні працівники, заклади професійної (професійно-технічної) освіти. 